\title{
Antifungal Activities of Essential Oils and Crude Extracts of Some Aromatic Plants Against Fusarium Rot of Trichosanthes dioica
}

\author{
Bina Wagle and Usha Budathoki \\ Central Department of Botany, Tribhuvan University \\ Kirtipur, Kathmandu \\ e-mail: itsmebina@hotmail.com
}

\begin{abstract}
This experiment was conducted for assessing the antifungal activities of essential oils and crude extracts of some aromatic plants against Fusarium rot of Trichosanthes dioica was at the Central Department of Botany. Pathogenicity test was taken for the confirmation of disease by transferring the inoculum from pure culture. For the control of the above fungus essential oils and extracts of five aromatic plants Zanthoxylum armatum, Mentha arvensis, Amomum subulatum, Valeriana jatamansi and Cymbopogon flexuosus were used. Each oil and extracts were diluted in different concentration in $80 \%$ acetone and in distilled water respectively. The value of minimum inhibitory concentration and percentage of mycelia growth inhibition of oil and extracts were obtained as, oil of C. flexuosus showed the higest fungitoxicity (100\%) at the 5.0 and $50 \mu \mathrm{lml}^{-1}$ concentration followed by Z. armatum, M. arvensis, A. subulatum and $V$. jatamansi were found to be 10 and $100 \mu \mathrm{lml}^{-1}$ respectively also the higest percentage of mycelial growth inhibitors were found to be C. flexuosus followed by A. subulatum, Z. armatum, M. arvensis and $V$. jatamansi. Similarly extracts of $C$. flexuosus followed by Z. armatum, A. subulatum, V. jatamansi and $M$.arvensis respectively.
\end{abstract}

Key words: inoculum, minimum inhibitory concentration, mycelial growth, pathogenicity

\section{Introduction}

Pointed gourd (Trichosanthes dioica Roxb.) is a tropical vegetable crop, commonly found in Terai region of Nepal.

\section{Post harvest damage}

The fruits of this plant suffer a lot of damage from fungal disease during summer season. The disease forms a luxuriant wooly mycelium on the affected fruit which appears as if wrapped in absorbent cotton. The tissue in the interior of the fruit becomes watery, soft and the decaying matter emits a bad odour. The species of Fusarium are the commonest and most widely distributed in soil and on organic substances, which cause fruit rot on different plants. The rot of pointed gourd is carried out by Fusarium solani (Mart.) Sacc, Synder \& Hansen.

The aim of the present study was to isolate the pathogen from infected pointed gourd and test its pathogenicity for studing the antifungal activities of oils and extracts of different aromatic plants against the F. solani.

\section{Methodology}

The research was carried out with the following steps: Collection of Host and Isolation of Pathogen The infected pointed gourd was collected from local market of Kathmandu valley .A piece of fungal colony was transferred aseptically on a petri plate containing PDA media and was incubated in inverted position in an incubator at $25 \pm 2^{\circ} \mathrm{C}$ for one week. After one week, the mycelial growth was observed under a compound microscope.

\section{Identification and pathogenicity test}

After studying and observing the characteristics features of the pathogen, it was identified as F. solani . The characteristics features of the fungus were 
identified with the help of standard literature (Booth, 1977). For pathogenicity test, the inoculum from the pure culture of $F$. solani was transferred to the healthy fruit. When incubated at $25 \pm 2^{\circ} \mathrm{C}$ for 7 days, the characteristics symptoms were produced, which were found to be similar with the symptoms on fruits previously collected.

\section{Maintenance of the pure culture}

The pure culture of F. solani was preserved by subculturing in several slants and plates containing PDA media.

\section{Preparation of one week old culture}

The fungus from pure culture was inoculated into PDA media containing petriplates, and incubated. After seven days the inoculum disc was taken from the culture for further experiment.

\section{Measurement of spore}

Measurement of spore was done by the help of ocular micrometer and stage micrometer. Ocular micrometer was calibrated by the help of stage micrometer.

Calculation of calibration factor applying the formula by:

One ocular division $=\stackrel{\text { No. of division on stage micrometer }}{\mathrm{X}} 10 \mu \mathrm{m}$ No. of division of ocular micrometer

Collection and extraction of essential oils and extracts of aromatic plants

Plant samples of V. jatamansi , A. subulatum, Z. armatum, $M$. arvensis and $C$. flexuosus each 50 gm.were collected out of these $V$. jatamansi and $A$. subulatum were hydro- distilled for 6-8 hours in Clevenger's apparatus in $500 \mathrm{ml}$ water for extraction of oiland rest were taken from HPPCL (Herb Production and Processing Company Limited). Similarly the crude extracts of aromatic plants were made by the help of mortar with pistal.

\section{Determination of yield of essential oils}

The volume of oil extracted was noted down. The yield of the essential oil was calculated in terms of $\%$ using the following formula.

$\%$ of essential oil $=\begin{gathered}\text { Volume of essential oil } \\ \text { Weight of sample }\end{gathered}$

\section{Dilution of essential oil and crude extract}

Essential oils were diluted into different concentration of $0.625,1.25,2.5,5.0,10.0, \mu^{-1} \mathrm{ml}^{-1}$ with $80 \%$ acetone and each crude extracts was diluted to different concentrations ,0.625, 1.25, 2.5, 5.0, 10.0,20, 30, 40, $50 \& 100 \mu \mathrm{lml}^{-1}$ with distilled water.

\section{Assessment of toxicity of oil and extract against fungal pathogen}

The toxicity of the oils was assessed by using the poisoned food technique $0.5 \mathrm{ml}$ of each concentration of each oil and extract was taken in presterilized cooled petriplate and $9.5 \mathrm{ml}$ of PDA media was poured on that with gently swirling to mix the contents thoroughly. In control set the essential oil was replaced by equal volume of acetone (80\%) and the control set of crude extract was replaced by equal volume of distilled water. The inoculum disc $(4 \mathrm{~mm}$ diameter) taken from the 7 days old culture of the pathogen, was placed aseptically at the centre of each plate and turned upside down in its position. The plates were then incubated at $25 \pm 2^{\circ} \mathrm{C}$ for 7 days. All the experiments were revised thrice. The percentage inhibition of mycelial growth of test fungus was calculated separately.

\section{Calculation of percentage of mycelial growth inhibition}

Fungitoxicity was assessed in terms of percentage inhibition of mycelial growth of test fungus .

$\%$ inhibition of mycelial growth $=\frac{g_{c}-g_{t}}{g_{c}} \times 100$

where,

$\mathrm{g}_{\mathrm{c}}=$ growth of mycelial colony after incubation in control set, i.e., diameter of colony in control set - diameter of inoculum disc

$\mathrm{g}_{\mathrm{t}}=$ growth of mycelial colony after incubation period in treatment set i.e. diameter of the colony in treatment set diameter of inoculum disc.

Determination of minimum inhibitory concentration of essential oil and extract

The minimum inhibitory concentration (MIC) is the concentration of any substance in the external medium which just inhibits cell division of a normal cell.

MIC has been expressed as the minimum dose of the essential oil and extract required for complete (100\%) inhibition of mycelial growth of the test fungus. 
Bina Wagle and Usha Budathoki/Antifungal Activities of Essential.........

Results and Disscussion Assessment of fungitoxicity of essential oils and extracts

Essential oils and extracts of different plant species showed different efficacies in the inhibition of the mycelial growth by measuring the colony size of culture plates.

Table 1. Percentage of inhibition of F.solani mycelial growth using essential oils of C. flexuosus

\begin{tabular}{|c|c|c|c|c|c|c|c|c|}
\hline \multirow[t]{2}{*}{ S.N } & \multirow{2}{*}{$\begin{array}{l}\text { Concent-ration } \\
\text { of oil } \\
\mu \operatorname{lml}^{-1}\end{array}$} & \multirow{2}{*}{$\begin{array}{l}\text { Inoculum } \\
\text { size (mm) }\end{array}$} & \multicolumn{3}{|c|}{ Colony size (mm) } & \multirow{2}{*}{$\begin{array}{l}\text { Mean colony } \\
\text { size }(\mathrm{mm})\end{array}$} & \multirow{2}{*}{$\begin{array}{l}\text { Mycelial } \\
\text { growth (mm) }\end{array}$} & \multirow{2}{*}{$\begin{array}{l}\% \text { of inhibition of } \\
\text { mycelial growth }\end{array}$} \\
\hline & & & I & II & III & & & \\
\hline 1 & 0 & 4 & 42 & 42 & 42 & 42.00 & 38.00 & 0.00 \\
\hline 2 & 0.62 & 4 & 19 & 18 & 19 & 18.67 & 14.67 & 61.40 \\
\hline 3 & 1.25 & 4 & 12 & 11 & 12 & 11.67 & 7.67 & 79.82 \\
\hline 4 & 2.50 & 4 & 8 & 7 & 8 & 7.67 & 3.67 & 90.35 \\
\hline 5 & 5 & 4 & 4 & 4 & 4 & 4.00 & 0.00 & 100.00 \\
\hline 6 & 10 & 4 & 4 & 4 & 4 & 4.00 & 0.00 & 100.00 \\
\hline
\end{tabular}

Minimum inhibitory concentration (MIC) $=5 \mu \mathrm{lml}^{-1}$

Essential oil of $C$. flexuosus showed mycelial inhibition as 0\%, 61.40\%, 79.82\%, 90.35\%, 100\% \& 100\% at 0, 0.625, 1.25, 2.5, 5.0, $10.0 \mathrm{\mu lml}^{-1}$ oil concentration against F.solani respectively.

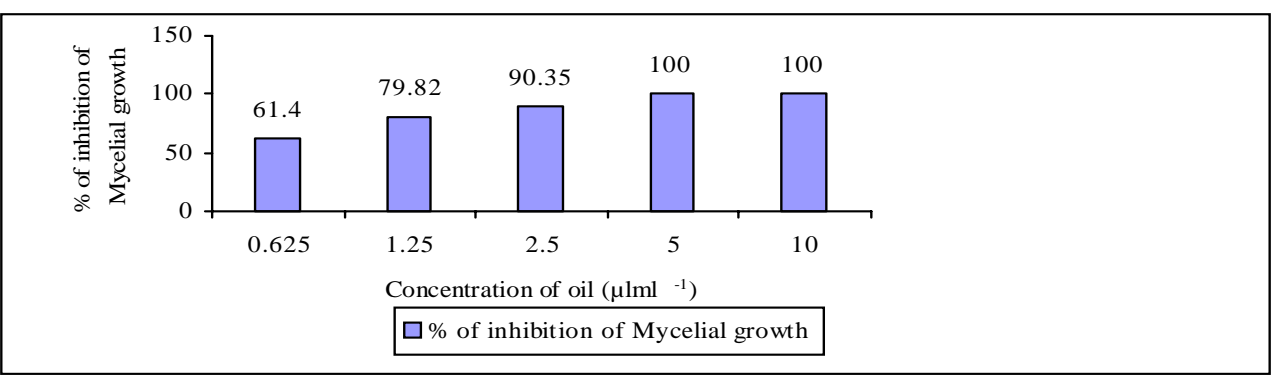

Fig 1. Percentage of antifungal activity of $C$. flexuosus oil against $F$. solani

Table 2. Percentage of inhibition of $F$. solani mycelial growth using extract of C.flexuosus

\begin{tabular}{|c|c|c|c|c|c|c|c|c|}
\hline \multirow{2}{*}{ S.N } & \multirow{2}{*}{$\begin{array}{l}\text { Concent-ration } \\
\text { of extract } \mu \mathrm{lml}^{-1}\end{array}$} & \multirow{2}{*}{$\begin{array}{l}\text { Inoculum size } \\
(\mathrm{mm})\end{array}$} & \multicolumn{3}{|c|}{ Colony size (mm) } & \multirow{2}{*}{$\begin{array}{l}\text { Mean colony } \\
\text { size (mm) }\end{array}$} & \multirow{2}{*}{$\begin{array}{l}\text { Mycelial } \\
\text { growth (mm) }\end{array}$} & \multirow{2}{*}{$\begin{array}{l}\% \text { of inhibition of } \\
\text { mycelial growth }\end{array}$} \\
\hline & & & I & II & III & & & \\
\hline 1 & 0 & 4 & 55 & 55 & 55 & 55.00 & 51.00 & 0.00 \\
\hline 2 & 0.62 & 4 & 50 & 50 & 51 & 50.33 & 46.33 & 9.15 \\
\hline 3 & 1.25 & 4 & 23 & 23 & 22 & 22.67 & 18.67 & 63.40 \\
\hline 4 & 2.50 & 4 & 18 & 18 & 18.5 & 18.17 & 14.17 & 72.22 \\
\hline 5 & 5 & 4 & 10 & 10 & 9.5 & 9.83 & 5.83 & 88.56 \\
\hline 6 & 10 & 4 & 9 & 9 & 9 & 9.00 & 5.00 & 90.20 \\
\hline 7 & 20 & 4 & 7 & 7 & 6.5 & 6.83 & 2.83 & 94.44 \\
\hline 8 & 30 & 4 & 6 & 5 & 5.5 & 5.50 & 1.50 & 97.06 \\
\hline 9 & 40 & 4 & 5 & 5.5 & 5 & 5.17 & 1.17 & 97.71 \\
\hline 10 & 50 & 4 & 4 & 4 & 4 & 4.00 & 0.00 & 100.00 \\
\hline 11 & 100 & 4 & 4 & 4 & 4 & 4.00 & 0.00 & 100.00 \\
\hline
\end{tabular}


Extract of Cymbopogon flexuosus showed mycelial inhibition as $0 \%, 9.15 \%, 63.40 \%, 72.22 \%, 88.56 \%$, $90.20 \%, 94.44 \%, 97.06 \%, 97.71 \%, 100 \%$ \& $100 \%$ at 0 ,
0.625, 1.25, 2.5, 5.0, 10.0, 20, 30, 40, 50, $100 \mathrm{\mu lml}^{-1}$ oil concentration against Fusarium solani respectively.

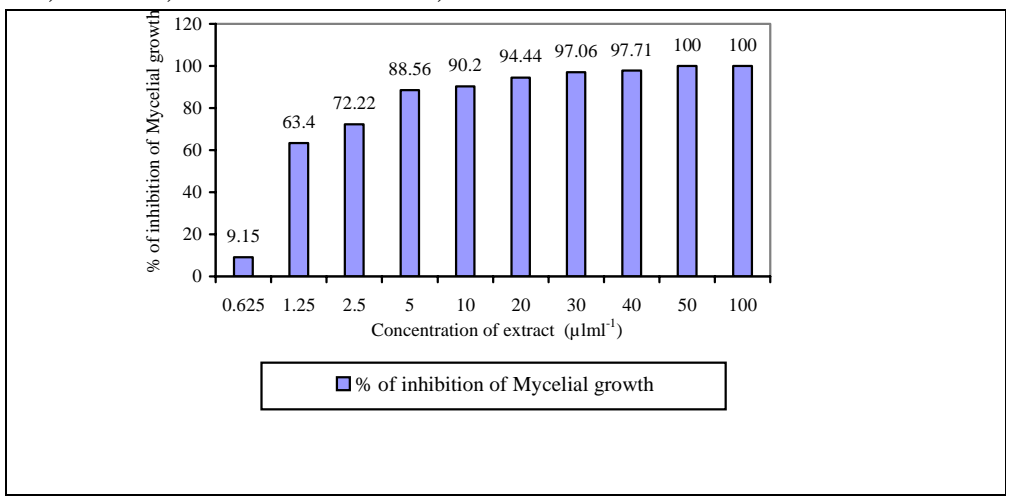

Fig. 2. Percentage of antifungal activity of $C$. flexuosus extract against $F$. solani Minimum Inhibitory Concentration (MIC) value of Aromatic plants oils and extracts of $C$. flexuosus was $5.0 \& 50.0 \mu \mathrm{lml}^{-1}$ similarly $10.0 \& 100.0 \mu \mathrm{lml}^{-1}$ for $M$. arvensis, V. jatamansi, A. subulatum and Z. armatum respectivelv.

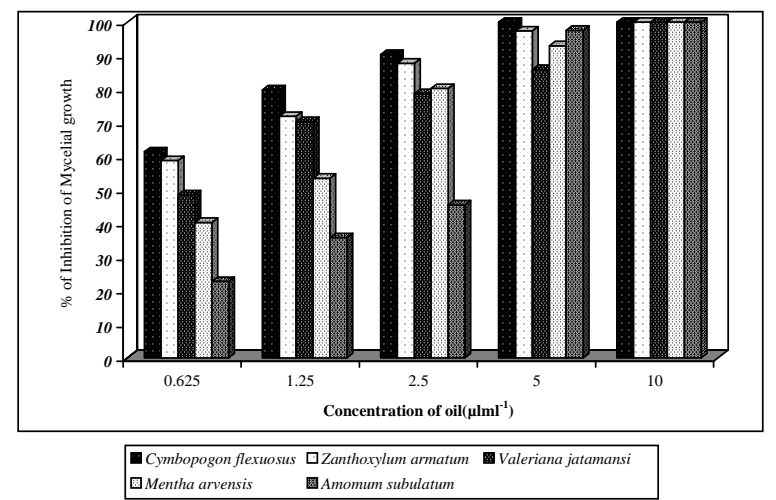

Fig. 3. Fungitoxicities of different essential oils in different concentrations

Table 3. Comparative fungitoxicities of different essential oils in different concentrations

\begin{tabular}{l|c|c|c|c|c|c}
\hline \multirow{2}{*}{ S.N } & $\begin{array}{c}\text { Concent- } \\
\text { ration of oil } \\
\mu \mathrm{lml}^{-1}\end{array}$ & $\begin{array}{c}\text { Cymbopogon } \\
\text { flexuosus }\end{array}$ & $\begin{array}{c}\text { Zanthoxylum } \\
\text { armatum }\end{array}$ & $\begin{array}{c}\text { Valeriana } \\
\text { jatamansi }\end{array}$ & $\begin{array}{c}\text { Mentha } \\
\text { arvensis }\end{array}$ & $\begin{array}{c}\text { Amomum } \\
\text { subulatum }\end{array}$ \\
\cline { 2 - 7 } 1 & 0 & 0 & 0 & 0 & 0 & 0 \\
2 & 0.625 & 61.4 & 58.77 & 48.61 & 40.35 & 22.76 \\
3 & 1.25 & 79.82 & 71.93 & 70.37 & 53.51 & 35.77 \\
4 & 2.5 & 90.35 & 87.77 & 78.7 & 80.26 & 45.53 \\
5 & 5 & 100 & 97.37 & 85.9 & 92.98 & 97.56 \\
6 & 10 & 100 & 100.00 & 100 & 100 & 100 \\
\hline
\end{tabular}


Bina Wagle and Usha Budathoki/Antifungal Activities of Essential.........

Table 4. Comparative fungitoxicities of different extracts in different concentrations

\begin{tabular}{c|c|c|c|c|c|c}
\hline \multirow{2}{*}{ S.N } & \multirow{2}{*}{$\begin{array}{c}\text { Concent-ration of } \\
\text { extract } \mu \mathrm{lml}^{-1}\end{array}$} & $\begin{array}{c}\text { Amomum } \\
\text { subulatum }\end{array}$ & $\begin{array}{c}\text { Zanthoxylu-m } \\
\text { armatum }\end{array}$ & $\begin{array}{c}\text { Valeriana } \\
\text { jatamansi }\end{array}$ & $\begin{array}{c}\text { Mentha } \\
\text { arvensis }\end{array}$ & $\begin{array}{c}\text { Cymbopogon } \\
\text { flexuosus }\end{array}$ \\
\cline { 3 - 6 } & 0 & 0 & 0 & 0 & 0 & 0 \\
2 & 0.625 & 30.72 & 26.47 & 18.95 & 14.38 & 9.15 \\
3 & 1.25 & 40.22 & 44.44 & 48.69 & 20.92 & 63.4 \\
4 & 2.5 & 84.97 & 77.45 & 53.59 & 26.80. & 72.22 \\
5 & 5 & 87.91 & 80.64 & 58.17 & 59.48 & 88.56 \\
6 & 10 & 89.87 & 86.27 & 62.75 & 68.28 & 90.2 \\
7 & 20 & 91.83 & 90.20 & 77.78 & 73.53 & 94.44 \\
8 & 30 & 94.77 & 90.52 & 84.97 & 77.78 & 97.06 \\
9 & 40 & 96.73 & 96.08 & 87.58 & 83.33 & 97.71 \\
10 & 50 & 98.37 & 99.02 & 98.37 & 90.52 & 100 \\
\hline
\end{tabular}

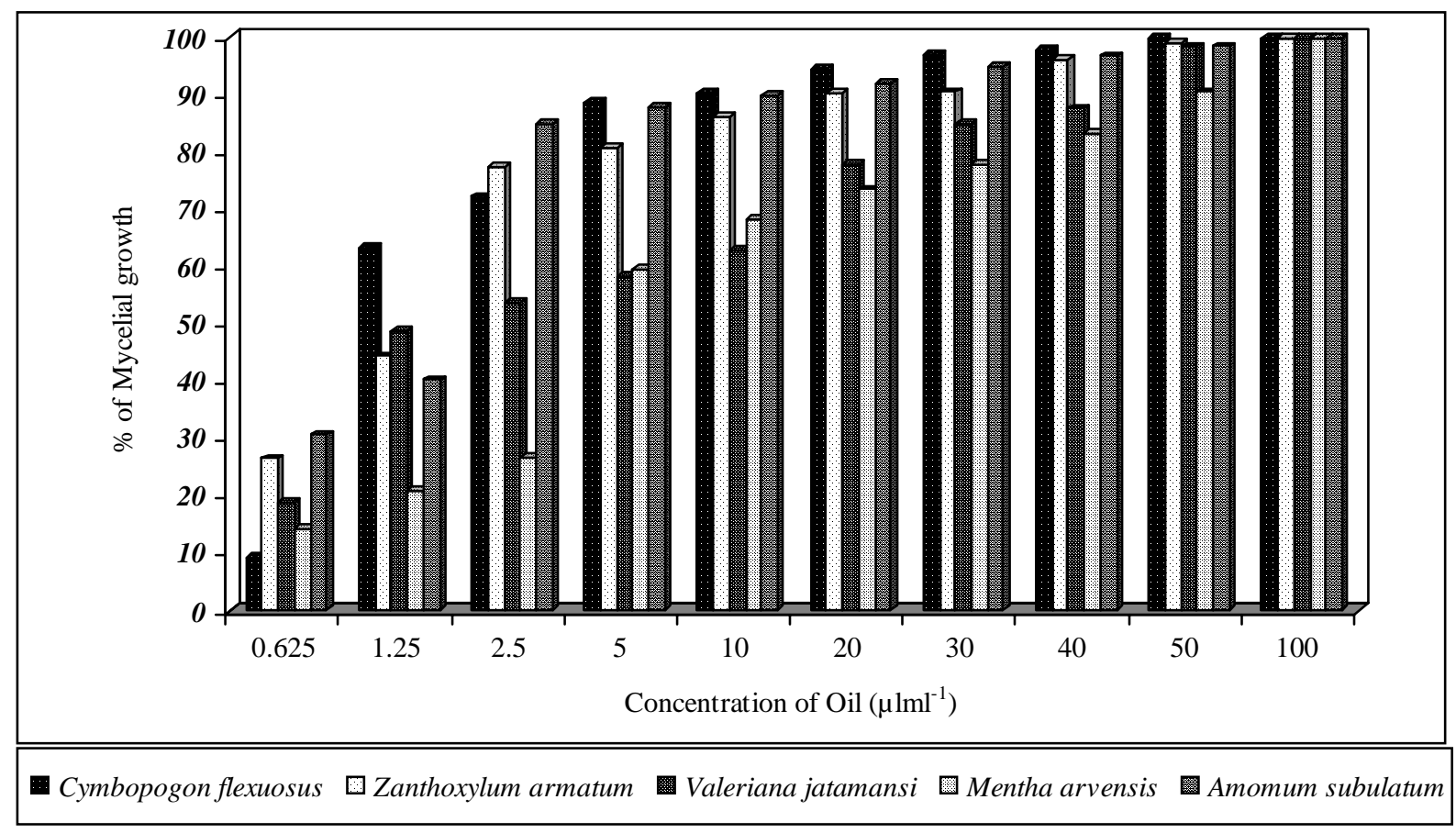

Fig 4. Fungitoxicities of different extracts in different concentrations

Out of five test plants, essential oil and extract of Cymbopogon flexuosus was found more effective in its fungitoxic properties and showed $100 \%$ inhibition of mycelial growth of the test fungus at MIC of $5.0 \mu \mathrm{lml}^{-1}$ and $50 \mu \mathrm{lml}^{-1}$ respectively. Similarly $Z$. armatum, V. jatamansi, $M$. arvensis, A.subulatum were found effective and showed $100 \%$ mycelial growth inhibition at $10 \mu \mathrm{lml}^{-1}$ and $100 \mu \mathrm{ml}^{-1}$ respectively. Also the percentage of mycelial growth inhibition were found to be different, according to their different concentration of each essential oil and extracts, the highest percentage of mycelial growth inhibition were found to be oil of $C$. flexuosus, Z. armatum, M. arvensis, A. subulatum and $V$. jatamansi respectively and similarly extracts of $C$. 
flexuosus, Z. armatum, A. subulatum, V. jatamansi and $M$. arvensis respectively. Thus, comparative fungitoxicities of five different essential oils and extracts were observed against $F$. solani .

A perusal of literature showed that, similar experiments for the control of $F$. solani using essential oils and extracts has not yet been done in Nepal. So this is the first study to assess fungitoxicities of essential oils and extract against $F$. solani. This research work can be applicable for commercial scale of inhibitory activities.

\section{Acknowledgements}

The authors would like to express their sincer thanks to all staffs of the Central Department of Botany, T.U. for their kind support during the researchwork.

\section{References}

Booth, C. 1977. Fusarium: Laboratory guide to the identification of Major species, Commonwealth Mycologocal Institute, Kew, Surrey, U.K.

Faweett, C.H. and D.M, Spencer. 1966. Annals of Applied Biology 60:87-96.
Faweett, C.H. and D.M. Spencer. 1970. Plant Chemotherapy with Natural Products. Ann. Rev. Phytopath. 8:403-418.

Manandhar, A. 2005. Assessment for Antifungal Activities of Plant Essential Oils Against Bipolaris sorokiniana. M.sc dissertation, Tribhuvan University, Kathmandu, Nepal.

Mehrotra, R. S. and A. Aggarwal. 2003. Plant Pathology, Second edition, Tata Mc Graw-Hill Publishing Company Limited New Delhi 11 (263):243-265.

Naik, M.K. 2003. Challenges and opportunities for research in soil- borne Plant Pathogen with Special reference to Fusarium species. Indian Journal of Mycology and Plant Pathology 33 (1):1-14.

Pandey, B. P. 2001. Plant Pathology: Pathogen and plant diseases. S. Chand and Company Ltd. New Delhi. 423.

Parajuli, R.R., R.D. Tiwari., R. P. Chaudhary and V. N. Gupta. 2005. Fungitoxicity of the essential oil of some aromatic plants of Manang against Alternaria brassicicola Scientific World 3:39-43.

Shrestha, S. 2005. Postharvest disease (sour rot) of Tomato (Lycopersicon esculentum) and Its Control by Some Local Plant Extracts. M.sc dissertation. Tribhuvan University, Kathmandu, Nepal.

Swaminathan, M.S. 1978. Inaugural address, first Botanical Conference, Meerut India ,pp.1-31. 